\title{
AN ANALYSIS ON THE RELATIONSHIP BETWEEN FUEL TAXES AND FUEL CONSUMPTION AND CURRENT DEFICIT: A CASE OF TURKEY
}

\author{
Murat GÜNGÜL ${ }^{1}$
}

\author{
Hakan ACAROĞLU²
}

\begin{abstract}
Obtaining energy appears to be a high-cost need almost all over the world. For specific countries, energy is a source of income rather than being a cost, for the reason of they have geographic or technological advantages. Energy is an income factor not during the production stages, but in the consumption stages through taxes for the other countries like Turkey. Among all energy sources, this situation is most clearly seen in fuel.

Both in Turkey and many countries in the world, high-rate taxes on fuel are received. So much so that these taxes are received on fuel in many places even exceeds the cost of obtaining fuel. And this affects flow of the economy from many aspects. For this reason, how the taxes on fuel affect fuel consumption and the current deficit, and the causality relationship between those, are examined in this study with the case of Turkey.

At the result of this study, it has been determined that there is a two-way relationship between the current deficit and fuel taxes, and a one-way relationship between fuel consumption and current deficit. Therefore, a change in current deficit is a reason for a change in fuel taxes; likewise, a change in fuel taxes is a reason for a change in current deficit. In addition to this, a change in fuel consumption is a reason for the change in current deficit. Any relation was not determined for the other cases.

The results were obtained by the help of Granger Causality Tests. The data set was taken from Central Bank of the Republic of Turkey, Turkish Statistical Institute, Energy Market Regulatory Authority, Revenue Administration and Petroleum Industry Association databases covering the years of 1996-2017.
\end{abstract}

Keywords: Fuel Taxes, Current Deficit, Fuel Consumption, Granger Causality Test.

JEL Code: H20, H71, Q43

\section{Introduction}

The relationship between energy consumption and economic growth has recently become an interesting area for economists and politicians. The relationship between energy consumption and economic growth or energy consumption and GNP have become frequently examined issues (Kwakwa, 2012: 34). In this context, a special distinction of energy consumption was examined under the heading of fuel, and the economic growth was examined under the heading of current account deficit in this study.

Fuel consumption is a very good tax item for the authorities due to its low demand elasticity. In fact, the taxes on fuel can be several times more the cost of obtaining fuel. Fuel energy is one

\footnotetext{
1 PhD Student, Eskişehir Osmangazi University, Institute of Social Sciences, Department of Economics, muratgungul@hotmail.com

2 Assoc. Prof. Dr., Eskişehir Osmangazi University, Faculty of Economics and Administrative Sciences, Department of Economics, hacaroglu@ogu.edu.tr
} 
of the most important energy sources for motor vehicles, ships and aircrafts; and for ecological, geopolitical, economic and political reasons, it has such a great place in taxation.

Thus, the main objective of the study will be to analyze whether the high taxes on fuel oil affect the current account deficit of Turkey, a country that consumes fuel and, therefore, imports energy, and whether there is a causal relationship between them.

\section{Collection of Tax on Fuel}

With the Special Consumption Tax Law, taxes have started to be collected under the single roof from the manufacture and import of motor vehicles, to tobacco and tobacco products, alcoholic beverages, petroleum and petroleum products, solvent products, electrical appliances and luxury goods (Tülümçe \& Özpençe, 2014: 281). Therefore, with the new tax law, different indirect taxes on fuel oil have been repealed and SCT and VAT have been started to be applied as a substitution.

Table 1. Fuel Sample Price Formation

\begin{tabular}{|l|l|l|}
\hline Description of the calculation & Identifier & Calculation \\
\hline Duty Free Refinery Price & $\mathrm{a}$ & 2,1 \\
\hline SCT: & $\mathrm{b}$ & 2,37 \\
\hline EMRA Share & $\mathrm{c}$ & 0,03 \\
\hline Total Refinery Price w/o VAT & $\mathrm{d}=\mathrm{a}+\mathrm{b}+\mathrm{c}$ & 4,5 \\
\hline Refinery Output VAT Load & $\mathrm{e}=\mathrm{dx} \% 18$ & 0,67 \\
\hline Total Warehouse Selling Price & $\mathrm{f}=\mathrm{d}+\mathrm{e}$ & 5,17 \\
\hline $\begin{array}{l}\text { Distribution Company and Dealer Profit } \\
\text { (12\%) }\end{array}$ & $\mathrm{g}=\mathrm{dx} \% 12$ & 0,54 \\
\hline VAT on Fuel Dealer After Sales & $\mathrm{h}=(\mathrm{d}+\mathrm{g}) \mathrm{x} \% 18$ & 0,91 \\
\hline Total Retail Price & $\mathrm{i}=\mathrm{d}+\mathrm{g}+\mathrm{h}$ & 5,95 \\
\hline Total Tax Burden & $\mathrm{j}=\mathrm{b}+\mathrm{c}+\mathrm{h}$ & $\mathbf{3 , 3 1}$ \\
\hline Duty Free Refinery Price & $\mathrm{j} / \mathrm{i}$ & $\mathbf{0 , 5 5}(\% \mathbf{5 5})$ \\
\hline
\end{tabular}

Source: (EPDK, 2018), (KantarcI, 2018: 233), Calculation was made by the author.

While the final price of the fuel is generated in Table 1, an add-on is made over many items based on duty-free refinery price and the consumer sales price is formed accordingly. The remarkable point here is the fact that VAT is based on the calculation of the tax base resulting from the addition of SCT and EMRA Share. In other words, the tax's tax is collected.

The EMRA reports show that Turkey has one of the lowest tax rates with a tax rate of $54.92 \%$ within the European Union member countries (for non-leaded gas 95 octanes). This rate is lower than the EU 28 countries weighted average with a rate of $60.18 \%$, lower than Italy with $64.54 \%$ and lower than Germany with a rate of 63.18\% (EPDK, 2018). 


\section{Methodology and Empirical Results}

The causality relationship between two or three variables is determined using Granger Causality Method. This method shows the existence and direction of causality relationship between variables (Granger, 1969: 428). Therefore, the taxation of fuel in Turkey, the fuel consumption and the causality relationship between the current deficit will be tested using the Granger Causality Test. The data set was acquired from Central Bank of the Republic of Turkey, Turkish Statistical Institute, Energy Market Regulatory Authority, Revenue Administration and Petroleum Industry Association databases covering the years between 1996-2017. The stability of the variables was tested before the relationship between these variables was established. The ADF test, formulated by Dickey and Fuller, will be used for the stability test (Dickey \& Fuller, 1979). The delay length was found to be 4 and the findings obtained from the test are shown in Table 2.

Table 2. ADF Test, Data Level Representation.

\begin{tabular}{|l|l|l|l|}
\hline \multirow{2}{*}{ Variables } & \multicolumn{3}{|c|}{ Data Level } \\
\cline { 2 - 4 } & Constant & $\begin{array}{l}\text { With Constant And } \\
\text { Trend }\end{array}$ & $\begin{array}{l}\text { With No Constant And } \\
\text { Trend }\end{array}$ \\
\hline AUAV & $\begin{array}{l}3.347696 \\
1.0000^{*}\end{array}$ & $\begin{array}{l}-0.246801 \\
0.9867^{*}\end{array}$ & $\begin{array}{l}7.031123 \\
1.0000^{*}\end{array}$ \\
\hline AT & -1.920642 & -2.610056 & 0.724499 \\
& $0.3161^{*}$ & $0.2801^{*}$ & $0.8618^{*}$ \\
\hline CA & -1.649697 & -3.005149 & -0.567520 \\
& $0.4409^{*}$ & $0.1539^{*}$ & $0.4592^{*}$ \\
\hline
\end{tabular}

Abbreviations: AUAV:Fuel Taxes, AT:Fuel Consumption, CA:Current Deficit .

* : Prop (Forecast) value

As seen in Table 2, variables are constant at the data level; and are not significant at $5 \%$ significance level in with constant/trend and without constant/ trend forms. This shows that the variables are not stable at the data level.

Table 3. ADF Test, First Degree Difference

\begin{tabular}{|l|l|l|l|}
\hline \multirow{2}{*}{ Variables } & \multicolumn{3}{|c|}{ First Order Differences } \\
\cline { 2 - 4 } & Constant & $\begin{array}{l}\text { With Constant And } \\
\text { Trend }\end{array}$ & $\begin{array}{l}\text { With No Constant } \\
\text { And Trend }\end{array}$ \\
\hline AUAV & -3.382578 & -5.338858 & 1.067926 \\
& $\mathbf{0 . 0 2 4 3 ^ { * }}$ & $\mathbf{0 . 0 0 1 9 ^ { * }}$ & $0.9183^{*}$ \\
\hline AT & -2.032174 & -2.627872 & -1.967905 \\
& $0.2716^{*}$ & $0.2737^{*}$ & $\mathbf{0 . 0 4 9 5 ^ { * }}$ \\
\hline CA & -5.399861 & -5.249655 & -5.417894 \\
& $\mathbf{0 . 0 0 0 3}^{*}$ & $\mathbf{0 . 0 0 2 3 ^ { * }}$ & $\mathbf{0 . 0 0 0 0 ^ { * }}$ \\
\hline
\end{tabular}


When the first degree differences of the variables are taken, it is seen that the series become stable. When Table 3 is examined, it is seen that when the first degree differences of the variables are taken, They are significant at $5 \%$ significance level, meaning that the variables are first-degree stable.

Once the variables became stable, the model was established as follows (Granger, 1969: 436).

$$
\begin{aligned}
& \mathrm{AUAV}_{\mathrm{t}}=\sum_{i=1}^{m} \alpha_{\mathrm{i}} \mathrm{AUAV}_{\mathrm{t}-\mathrm{i}}+\sum_{j=1}^{m} \quad \beta_{\mathrm{i}} \mathrm{AT}_{\mathrm{t}-\mathrm{j}}+\sum_{i=1}^{m} \delta_{\mathrm{i}} \mathrm{CA}_{\mathrm{t}-1}+\epsilon_{\mathrm{t}} \\
& \mathrm{AT}_{\mathrm{t}-\mathrm{j}}=\sum_{i=1}^{m} \partial_{\mathrm{i}} \mathrm{AT}_{\mathrm{t}-\mathrm{j}}+\sum_{j=1}^{m} \vartheta_{\mathrm{i}} \mathrm{AUAV}_{\mathrm{t}-\mathrm{j}}+\sum_{i=1}^{m} \rho_{\mathrm{i}} \mathrm{CA}_{\mathrm{t}-1}+\epsilon_{\mathrm{t}} \\
& \mathrm{CA}_{\mathrm{t}-\mathrm{i}}=\sum_{i=1}^{m} \varphi \mathrm{iCA}_{\mathrm{t}-\mathrm{i}}+\sum_{i=1}^{m} \omega_{\mathrm{i}} \mathrm{AUAV}_{\mathrm{t}-\mathrm{j}}+\sum_{i=1}^{m} \aleph_{\mathrm{i}} \mathrm{AT}_{\mathrm{t}-\mathrm{j}}+\epsilon_{\mathrm{t}}
\end{aligned}
$$

Granger Causality Test was performed once the model was established. The empirical results obtained from the test are shown in Table 4.

Table 4. Granger Causality Test Result

\begin{tabular}{|l|l|l|l|l|l|}
\hline $\begin{array}{l}\text { Dependent } \\
\text { Variable }\end{array}$ & Zero Hypothesis $\left(\mathrm{H}_{0}\right)$ & $\begin{array}{l}\text { Chi-Square } \\
\text { Test }\end{array}$ & $\begin{array}{l}\text { Estimate } \\
\text { Value }\end{array}$ & Decision & Conclusion \\
\hline AUAV & $\begin{array}{l}\text { AT is not the Granger } \\
\text { cause of AUAV }\end{array}$ & 1.832271 & 0.4001 & Confrimed & $\begin{array}{l}\text { AT is not the Granger } \\
\text { cause of AUAV }\end{array}$ \\
\cline { 2 - 6 } & $\begin{array}{l}\text { CA is not the Granger } \\
\text { cause of AUAV }\end{array}$ & 10.87214 & $\mathbf{0 . 0 0 4 4}$ & Refused & $\begin{array}{l}\text { CA is the Granger cause } \\
\text { of AUAV }\end{array}$ \\
\hline \multirow{2}{*}{ AT } & $\begin{array}{l}\text { AUAV is not the Granger } \\
\text { cause of AT. }\end{array}$ & 4.850810 & 0.0884 & Confrimed & $\begin{array}{l}\text { AUAV is not the Granger } \\
\text { cause of AT. }\end{array}$ \\
\cline { 2 - 6 } & $\begin{array}{l}\text { CA is not the Granger } \\
\text { cause of AT }\end{array}$ & 1.264128 & 0.5315 & Confrimed & $\begin{array}{l}\text { CA is not the Granger } \\
\text { cause of AT }\end{array}$ \\
\hline \multirow{2}{*}{ CA } & $\begin{array}{l}\text { AUAV is not the Granger } \\
\text { cause of CA }\end{array}$ & 8.637451 & $\mathbf{0 . 0 1 3 3}$ & Refused & $\begin{array}{l}\text { AUAV is the Granger } \\
\text { cause of CA }\end{array}$ \\
\cline { 2 - 6 } & $\begin{array}{l}\text { AT is not the Granger } \\
\text { cause of CA }\end{array}$ & 6.496542 & $\mathbf{0 . 0 3 8 8}$ & Refused & $\begin{array}{l}\text { AT is the Granger cause } \\
\text { of CA }\end{array}$ \\
\hline
\end{tabular}

According to the findings obtained from the empirical model, when the dependent variable was the taxes on fuel, since fuel consumption was not at $5 \%$ significance level, it was not significant; and the current account deficit was significant at $5 \%$ significance level. While the dependent variable was fuel consumption, a result could not be achieved at the $5 \%$ significance level for both the taxes on fuel and the current account deficit. When the current deficit was the dependent variable, a result was achieved at the level of $5 \%$ significance level for both the taxes on fuel and fuel consumption. Thus, as a result of the model, a two-way Granger Causality relationship was determined from the current account deficit to the taxes on fuel and a two-way Granger Causality relationship was also determined from the taxes on fuel to the current account deficit; and a one-way Granger Causality relationship was determined from fuel consumption to the current account deficit. 


\section{Conclusion}

In this study examining the effects of taxes on fuel consumption and current account deficit, empirical results were obtained for Turkey using the Granger Causality Test.

As a result of the study, it was determined that there is a two-way relationship between current account deficit and fuel taxes, and a one-way relationship between fuel consumption and current account deficit. In other words, a change in current account deficit is also the reason for the change in fuel taxes; likewise, a change in fuel taxes is the reason for the change in current account deficit. As for fuel consumption, a change in fuel consumption is the reason for the change in current deficit. No relationship was found for other cases.

Turkey is a country that imports energy. Turkey's energy import amount and current account deficit are very close. In fact, sometimes its energy import amount is even greater than its current account deficit. Therefore, the effect of fuel consumption on the current account deficit is a result parallel with the causal relationship obtained in the study. Moreover, one of the first attempts of the government to reduce imports was to increase the taxes against the increases in the current account deficit. These taxes are particularly for the areas that have a high impact on the current account deficit and affect the taxes on the fuel sector, which has a high share in imports. Therefore, the fact that a change in the current account deficit affects the taxes on fuel and that the taxes on fuel affect the current account deficit strengthens the parallelism between the theoretical results in the study and the results in practice.

\section{References}

Dickey, D.A. \& Fuller, W.A. (1979). "Distribution Of The Estimators For Autoregressive Time Series With A Unit Root", Journal Of The American Statistical Association, 74(366a), pp. 427-431.

EPDK. (2018). 2018 Yılı Nisan Ayı Petrol Ve LPG Piyasası Fiyatlandırma Raporu. http://epdk.gov. tr/Detay/Icerik/3-0-143/fiyatlandirma-raporu, (31/10/2018).

Granger, C. W. J. (1969). "Investigating Causal Relations By Econometric Models And CrossSpectral Methods", Econometrica, 37 (3), pp. 424-438.

Kantarcı, H.B. (2018). "Türkiye'de Akaryakıt Üzerinden Alınan Vergilerin OECD ve AB Ülkeleri ile Karşılaştrılması", Sosyoekonomi, 26(35), ss. 229-247.

Kwakwa, P. (2012). "Disaggregated Energy Consumption and Economic Growth in Ghana", International Journal of Energy Economics and Policy, 2 (1), pp. 34-40.

Tülümçe, S.Y. \& Özpençe, Ö. (2014). "Türkiye'de Özel Tüketim Vergisi Ve Cari Açık Arasındaki İlişkinin Analizi", Elektronik Sosyal Bilimler Dergisi, 13(49), ss. 280-291. 